\title{
The Effect of School Culture and Scout Extracurricular to the Prosocial Behavior of Students in Elementary School
}

\author{
Wahyu Nur 'Aida \\ Universitas Negeri Surabaya \\ Surabaya, Indonesia \\ wahyuaida16070855093@mhs.unesa.ac.id
}

\author{
Muhari \\ Universitas Negeri Surabaya \\ Surabaya, Indonesia \\ muhari@stkipbim.id
}

\author{
Harmanto \\ Universitas Negeri Surabaya \\ Surabaya, Indonesia \\ harmanto@unesa.ac.id
}

\begin{abstract}
This study aims: to analyze the significant effect of school culture on student's prosocial behavior, to analyze the significant effect of scout extracurricular on student's prosocial behavior, and to analyze the significant effect of school culture and scout extracurricular jointly to the prosocial behavior of learners. This study uses a quantitative approach. This research was conducted in elementary school with a population of 235 respondents and a sample of 70 respondents. The data collection technique which is used is questionnaires and documentation. Analysis of the research results using prerequisite analysis test is the normality test, linearity test, multicolonierity test, and heteroscedasticity test, and use multiple linear regression analysis. Related to the purpose of this study shows the results: the value of $t$ count $1.998>t$ tabel 1.996 means there is a significant effect of school culture on student's prosocial behavior, research results show $t$ count 5,549 > t tabel 1.996 means there is significant effect of Scout extracurricular on student's prosocial behavior, and the results showed $F$ count 79.607 > F tabel 3.13 means there is a significant effect together between school culture and Scout extracurricular jointly to the prosocial behavior of learners.
\end{abstract}

Keywords-school culture; scout extracurricular; prosocial behavior.

\section{INTRODUCTION}

Education is very important. Education is able to create quality human resources. Therefore, people today are competing to study or get the highest education. This is done with the aim to improve the quality of self and to achieve success in the career, because the public assumption about scholars is a scholar who certainly has advantages in terms of knowledge, skills, moral quality or character in behaving, faith and noble character. However, in fact the assumption has been shifted, because someone who has been educated with a higher education level that has the knowledge, skills and technical skills (hard skills) are superior, not necessarily have good moral quality or character (soft skill) able to achieve success in his career. This statement is evidenced from the results of research at Harvard University United. There are other factors that are also important considerations for measuring a person's success is through the person's behavior towards self-management with others or so-called soft skills.The expansion of relationships with communities and the formation of new ties with peers begin in the development of primary school age.

Based on the results of observations and interviews conducted by researchers to teachers in elementary school (Teacher, personal communication, May 12, 2017), it is noted that the behavior of prosocial learners in schools is still low. This is as expressed by teacher as a grade $6 \mathrm{~A}$ teacher, she said that "The children's attitude concerns here are still less to the surrounding, for example if there are friends who fight, only 1 or 2 children who want to intervene. It is still continued during the lesson. If the teacher leaves the class for a while, it would have been crowded since students in $6 \mathrm{~B}$ class can not be left. In this elementary school class B belongs to special children, special in the meaning of the students who need moree attention of their mischief". Other evidances that reflect the low behavior of prosocial learners are shown by the behavior of learners who do not respect the young teachers, arbitrarily, mock their friends, hit / fight their friends, say harsh words or impollite words, lack of caring attitude towards other friends, snapp at others, and other behaviors that tend to be socially unacceptable. The fact that there are distorted behaviors perpetrated by the learners still occurs.

Based on exposure to deviant behaviors that these learners do, these behaviors do not describe a behavior that spontaneously responds to a stimulus (event). Those can assist others who need help without considering the motive or 
benefit for the helper, such behavior. This is called prosocial behavior. If the problem persists, it still needs special attention from various parties such as parents, teachers and schools for learners to minimize the deviation behavior on positive activities.

The way to develop the children's prosocial behavior in school is through school culture and scout extracurricular. Through the school culture, it should be started from the behavior of teachers who exemplify positive behaviors to learners that will be reflected in the culture of the school. Then, the culture will indirectly become good habits and able to form prosocial behavior of learners, whether learners are inside or outside the classroom. Meanwhile, building prosocial behavior of learners can be integrated during the scout activities. Scout extracurricular is one of the right programs in instilling the value of character to the students. Therefore, the establishment of these values can form the prosocial behavior of learners in scout activities. These activities have been programed as best and as attractive as possible for learners.

Based on the above explanation and the phenomenon which exists, through the school culture and Scout extracurricular learners are trained and accustomed to behave prosocially in various activities. In connection with these problems, the researchers feel the need to conduct a deeper assessment through this research as a concrete manifestation of concerns about education issues, especially related to "The Effect of School Culture and Scout Extracurricular to The Prosocial Behavior of Students in elementary school”.

\section{METHOD}

This study used a quantitative approach. According to Arikunto [1] suggests quantitative research which is a research approach that many are required to use numbers. The reason why the authors use quantitative approach is to consider elemental clarity, namely objectives, subject, source of data, samples, research design, and data analysis. In addition, there are other factors that influence the selection of this research approach which are type of time, available funds and interests of the researchers.

The type of research is ex-post facto research. According to Riduwan [2] ex-post facto research is a study conducted to examine the events that have occurred and then look back to find out the factors that can cause the incident. In an ex-post facto study, the cause-and-effect relationship between subjects one and the other subjects is examined and cannot be manipulated, because ex-post facto research only reveals the symptoms that exist or have occurred.

This research was conducted in elementary school. The subjects were $3 \mathrm{~A}, 3 \mathrm{~B}, 4 \mathrm{~A}, 4 \mathrm{~B}, 5 \mathrm{~A}, 5 \mathrm{~B}, 6 \mathrm{~A}$ and $6 \mathrm{~B}$ classes with a population of 235 students, but the researchers only used 70 students as the sample. The sample selection was selected randomly.

Data collection techniques in this study used questionnaires and documentation. The questionnaires used include the questionnaire of school culture, scout extracurricular questionnaires and the questionnaire of learners' prosocial behavior. The preparation of the questionnairse and the development of this research instruments were based on the indicators derived from some experts' ideas. The statements set forth in the questionnaire are prepared and developed by the researchers in the form of Likert scale with a closed statement that was the answer to the proposed statement has been provided. This study used five alternative answers to the instrument that is very agree, agree, quite agree, disagree and strongly disagree that there was a composition that starts from a positive statement to a negative statement. Moreover, there was also a negative statement to a positive statement. For positive statements which strongly agree the score is 5, agree with score 4 , quite agree with score 3 , disagree with score 2 and strongly disagree with score 1 . While score for negative statement strongly agree with score 1 , agree with score 2 , moderate with score 3 , disagree with score 4 and strongly disagree with score 5 .

Data analysis in this research is using multiple linear regression analysis. Before the multiple linear regressions analysis was done, prerequisite analysis namely test normality test, linearity test, multicolonierity test and heteroscedasticity test was conducted. As for the instrument performed validity testing and reliability.

\section{RESULTS AND DISCUSSION}

\section{A. Instruments of Validity and Reliability}

The validity test result of the school culture questionnaire stated that from 40 statements in the questionnaire, there are 2 items of invalid statement which must be omitted. The validity test result of the extramurik exam questionnaire stated that 35 statements of the questionnaire were valid. Likewise, the test validity of prosocial behavior also stated that 40 statements of the questionnaire were valid. Therefore, for all statements that have been declared valid can be used as a tool to collect data.

Related to the reliability test results, it used Cronbach Alpha value from school culture variables, scout extracurricular and prosocial behavior of learners. The results were reliable because in accordance with the rules of decision making that the value $r>r$ table as for the value of $r$ obtained each item of 0.423 .

\section{B. Test Prerequisite Analysis}

\section{- Normality Test}

According to Riduwan [2], normality test is to test weather the data is normaly or not normally distributed to be analyzed (find out whether the residual value is normally distributed or not).

The results of normality test of school culture variables $\left(\mathrm{X}_{1}\right)$, scout extracurricular $\left(\mathrm{X}_{2}\right)$, and prosocial behavior of learners (Y) have been known that the value of significance is equal to 0.200 . This indicates that $0.200>0.05$ has fulfilled the requirement that significance value $>0.05 \mathrm{Ha}$ is accepted, it means that there was normal residual distributed value as stated by Irianto [3]. Further data can be added as an analytical prerequisite test. 


\section{- Linierity Test}

According Winarsunu [4] linearity test is intended to determine the form of relationship between independent variables and dependent variables. Linear means that whether the two data or the connected variable is in a straight line. Linearity can also mean the nature of the linear relationship between variables. It means that any changes that occur in one variable will be followed by other changes in the parallel variables.

In order to know the linearity of a test, it can be obtained from the $F$ value which $F$ value $>F$ table. Then the independent variable has a linear relationship between the independent variable and the dependent variable [5].

As for the relationship between school cultures variables $\left(\mathrm{X}_{1}\right)$ on prosocial learners' behavior variable (Y) or on the other hand, it obtained $\mathrm{F}$ value of 2.079 (seen in table Anova) and F tabel of 3.13. Therefore, it can be written as $2.079<3.13$. In sum, the value of $F$ value $<\mathrm{F}$ table showed that there was a linear relationship between independent variables with dependent variable or vice versa.

While for the relationship between Scout extracurricular variable $\left(\mathrm{X}_{2}\right)$ on prosocial learners' behaviora variable $(\mathrm{Y})$ or vice versa, it obtained $\mathrm{F}$ value of 1.057 (seen in table Anova) and $\mathrm{F}$ table of 3.13. It can be written as $1.057<3.13$. It can be concluded that the value of $F$ value $<F$ table showed that there is a linear relationship between the independent variable with the dependent variable or vice versa.

After the linearity test conducted, it turns out to be two independent variables which are the school culture variables $\left(\mathrm{X}_{1}\right)$ and the scout extracurricular $\left(\mathrm{X}_{2}\right)$. Those has met the linearity test with the result level of $F$ value $<\mathrm{F}$ table. Therefore, this result can be used to conduct multiple linear regression tests.

\section{- Multicollonierity Test}

Multicollonearity test is done to test whether or not appears a correlation between independent variables one with other independent variables in the regression model. If there is a high correlation between the independent variables, then the relationship between independent variables to the dependent variable to be disturbed.

Mullticollonearity is discovered through tolerance value and VIF value in accordance with rule of decision making. The rules of decision making are followed by the statement by Gozali [6].

Based on the tolerance value, if Tolerance value is > 0.10 , then there is no multicolonierity. However, if tolerance value is $<0.10$, then there is multicolonierity. According to the value of VIF (Variance Inflation Factor), if the VIF value is $<10.00$, then there is no multicolonierity occured. If the value of VIF is $>10.00$ then there is multicolonierity.

Based on the result of tolerance value and VIF value, it obtained that the school culture variable of tolerance value is $0.332>0.10$, and the result of VIF value is $3,010<10.00$. Meanwhile, the Scout extracurricular variable tolerance value is $0.332>0.10$ and the value of VIF is $3.010<10.00$. Therefore, it can be concluded that the two cultural variables school $\left(\mathrm{X}_{1}\right)$ and scout extracurricular variable $\left(\mathrm{X}_{2}\right)$ between these independent variables do not occur multikolorineritas. Thus, the two independent variables can be used as independent variables.

\section{- Heteroscedasticity Test}

According Ghozali [6] the heteroscedasticity test is used to see if there is inequal variance from one residual to another. Regression models that meet the requirements or regression models are can be good are there is a similarity of variance from one residual observation to another observation remained or called homoskedastisitas or no heteroscedasticity.

The way to see to detect whether there is or not heteroskedasticity is to see the plot graph between the predicted value of the bound variable ZPRED and the residual SPRESID. The identification can be done by looking at whether there is a certain pattern on the Scatterplot chart between SRESID and ZPRED where the $\mathrm{Y}$ axis is predicted $\mathrm{Y}$ axis, and the $\mathrm{X}$ axis is residue that has been distudenized.

To find out a particular pattern on the Scatterplot to analyze the data, those are other data points spreaders above and below or around the number 0 . The points do not collect only above or below only. The spread of data points should not form a wavy pattern, widened pattern which can be narrowed and widened again, and the spread of data points are not patterned. Thus, it can be said that there is no problem of heteroscedasticity, until a good and ideal regression model can be fulfilled. The results of the Scatterplot graph can be described as follows.

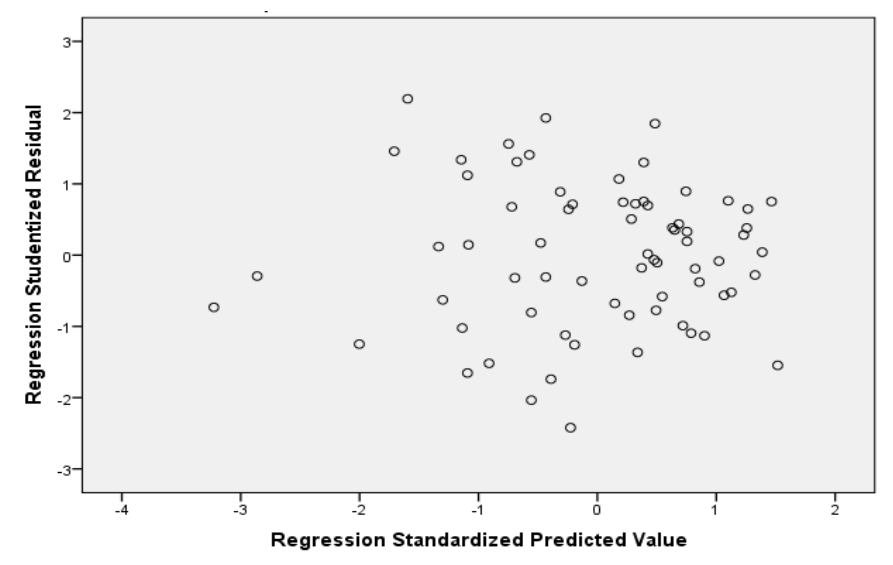

Fig. I Scatterplot Graphic 
C. Regression Testing (Multiple Liniear Regression Analysis)

The equations in multiple linear regression analysis are as follows.

$$
\mathrm{Y}=\mathrm{a}+\mathrm{b} \mathrm{X}_{1}+\mathrm{c} \mathrm{X}_{2}
$$

Based on the test results have been obtained equation: $\mathrm{Y}=$ $3,174+0,292 \mathrm{X}_{1}+0,779 \mathrm{X}_{2}$

Information:

$$
\begin{array}{ll}
\mathrm{Y} & =\text { Prosocial Behavior of Learners } \\
\mathrm{X}_{1} & =\text { School Culture } \\
\mathrm{X}_{2} & =\text { Scout Extracurricular } \\
\mathrm{a} & =\text { Constants } \\
\mathrm{b} \text { dan c } & =\text { Regression Coefficient }
\end{array}
$$

Based on the regression equation above, it explains that the constant is 3.174 . This shows that the great prosocial behavior of learners is 3.174 if the school culture variable $\left(\mathrm{X}_{1}\right)$ and scout extracurricular $\left(\mathrm{X}_{2}\right)$ is zero or constant.

School Culture $\left(X_{1}\right)$

Coefficient of regression for school culture is positive. It is equal to 0.292. If school culture go up one unit, prosocial behavior of learners will rise equal to 0.292 unit with assumption that the other variable is constant.

Scout Extracurricular $\left(\mathrm{X}_{2}\right)$

Regression coefficient for acout extracurricular is positive that is equal to 0.779 . It means that if school culture go up one unit, prosocial behavior of learners will rise equal to 0.779 unit with assumption that the other variable is constant..

\section{Hypothesis Testing}

- $\mathrm{t}$ test

\section{Hypothesis Testing 1}

Hypothesis testing 1 has been obtained significant value. For the influence of $\mathrm{X}_{1}$ to $\mathrm{Y}$, the significant value is $0.05=0.05$ or $\mathrm{t}$ value $1.998>\mathrm{t}$ tabel 1,996 , so it can be concluded that $\mathrm{Ha}$ accepted which means there is influence between school culture variable $\left(\mathrm{X}_{1}\right)$ to prosocial learners behavior variable $(\mathrm{Y})$. The influence of school culture variables $\left(\mathrm{X}_{1}\right)$ on prosocial learners' behavioral variable (Y) of 0.292 or equal to $29.2 \%$ is considered significant. This is reflected in the significant number of school culture variables $\left(\mathrm{X}_{1}\right)$ of 0.05 .

\section{Hypothesis Testing 2}

The test has been obtained significant value for the effect of $\mathrm{X}_{2}$ on $\mathrm{Y}$ which is equal to the significant value of $0.00<0.05$ or $t$ value $5,549>t$ tabel 1.996. It can be concluded that Ha accepted which means that there is influence between scout extracurricular variable $\left(\mathrm{X}_{2}\right)$ to prosocial learners' behavior variable $(\mathrm{Y})$. The influence of scout extracurricular variable $\left(\mathrm{X}_{2}\right)$ to the prosocial learners' behavior variable $(\mathrm{Y})$ is 0.779 or equal to $77.9 \%$ or considered significant. This reflected in the significant number of scout extracurricular $\left(\mathrm{X}_{2}\right)$ variables of 0.000 .

\section{- ANOVA}

The test has obtained significant value for the influence of $\mathrm{X}_{1}$ and $\mathrm{X}_{2}$ simultaneously (together) on the prosocial learners behavior of $(\mathrm{Y})$ with significant value $0,00<0,05$ and $F$ value 79,607 $>F$ table 3.13. Therefore, it can be concluded that $\mathrm{Ha}$ is accepted which means that there is influence between school culture variable $\left(\mathrm{X}_{1}\right)$ and scout extracurricular variable $\left(\mathrm{X}_{2}\right)$ to student prosocial behavioral variable $(\mathrm{Y})$.

In addition, through the coefficient determination of $\mathrm{R}$ Square value of 0.704 which means that the influence of school culture variables $\left(\mathrm{X}_{1}\right)$ and scout extracurricular variable $\left(\mathrm{X}_{2}\right)$ simultaneously (together) to the prososial learners behavior variable $(\mathrm{Y})$ is $70.4 \%$, while $29.6 \%(100 \%-70.4 \%)$ is influenced by other factors.

Therefore, to prove that the regression model in this research is correct or not, there is a linear correlation between school culture and extracurricular scouting toward the prosocial behavior of learners using significance value (Sig.) It can be seen in Anova table based on the following hypothesis.

Ha: There is a linear relationship between school culture $\left(\mathrm{X}_{1}\right)$ and scout extracurricular $\left(\mathrm{X}_{2}\right)$ towards the behavior of prosocial learners $(\mathrm{Y})$.

Ho: There is no linear correlation between school culture $\left(X_{1}\right)$ and Scout extracurricular $\left(X_{2}\right)$ towards prosocial behavior of learners $(\mathrm{Y})$.

Testing is done by using significance number or Sig. with the following statement.

If the significance of the study is $<0.05, \mathrm{H}_{\mathrm{a}}$ is accepted and $\mathrm{H}_{\mathrm{o}}$ rejected.

If the significance of research is $>0.05, \mathrm{H}_{\mathrm{a}}$ is rejected and $\mathrm{H}_{\mathrm{o}}$ accepted.

Based on the calculation on the table Anova, it is obtained significance number (Sig.) of 0.000 . Therefore, $\mathrm{H}_{\mathrm{a}}$ is accepted and $\mathrm{H}_{\mathrm{o}}$ is rejected. This means that there is a linear correlation between school culture $\left(\mathrm{X}_{1}\right)$ and scout extracurricular $\left(\mathrm{X}_{2}\right)$ toward prosocial behavior of learners $(\mathrm{Y})$, school culture variable $\left(\mathrm{X}_{1}\right)$ and scout extracurricular variable $\left(\mathrm{X}_{2}\right)$. It is true that the $X_{1}$ and $X_{2}$ influence student prosocial behavior variable $(\mathrm{Y})$. So the conclusion is that the regression model discussed earlier is correct and feasible.

\section{E. The Effect of School Culture and Scout Extracurricular to The Prosocial Behavior of Learners.}

According to Zamroni [7], school culture is a pattern of values, principles, traditions, and habits which are formed and developed for long periods of time and became a grip which is believed by school residents to encourage the emergence of 
their attitudes and behavior. School residents according to Law no. 20 Year 2003 about Sisdiknas [8] consist of learners, educators, principals, educators and school committee.

The school culture also believes that the school's cultural norms and values can influence the school's functions because these things are closely related to all habits that affect the behavior of the school community. This is in line with Maslowski [9] that defines school culture in the form of basic assumptions, norms and values, cultural artefacts owned by the school residents. It is believed that school residents can affect their function in school.

The development of school culture is done through selfdevelopment activities such as routine activities, spontaneous activities, exemplary, and conditioning (center for the development of cultural education and character of the nation). If the school culture has good act reputation, especially the prosocial behavior that has been entrenched in a school is running well and already attached to each individual of the school, then indirectly good behaviors will be embedded in the individual personality. Prosocial behavior also can be interpreted as any action that benefits others. In general, the term is applied to actions that do not provide immediate benefits to the person who do the action and even contain a certain degree of risk [10].

The process of other activities that also affects the prosocial behavior of learners also can be seen through extracurricular activities, scout. According to Gunawan [11], scout extracurricular is a scout's curricular program which involves the activities in and / or outside the school environment with not specified time allocation in the curriculum to assist the development of learners according to the needs, talents and interests which performed in interesting manners. The purpose and function of the scout by Rahmatika [12] are to build individual with personality, faith, noble character, patriotic soul, obey the law, discipline, respect the noble values of the nation, physically and mentally healthy and become a man who has soul of Pancasila, faithful and obedient to NKRI, and well mannered in the society.

The results showed that the variables of school culture and Scout extracurricular on the behavior of prosocial learners simultaneously (together) have a significant effect with the effect of 0.704 . The contribution of school culture amounted to 0.292 with a significance value of 0.050 which resulted in the influence of school culture $\left(\mathrm{X}_{1}\right)$ on the behavior of prosocial learners (Y). While Scout extracurricular contributes 0.779 with a significance value of 0.000 smaller than 0.05 which results in the influence of Scout extracurricular $\left(\mathrm{X}_{2}\right)$ on the behavior of prosocial learners $(Y)$. Therefore, because the results obtained are significant, the school culture and scout extracurricular are important variables to consider in terms of forming prosocial behavior of learners.

Therefore, it can be concluded that by knowing the contribution value of each independent variables, namely school culture $\left(\mathrm{X}_{1}\right)$ with the value of $29.2 \%$ and extracurricular Scout $\left(\mathrm{X}_{2}\right)$ the value of $77.9 \%$, it can be concluded that scout extracurricular as free variable $\left(\mathrm{X}_{2}\right)$ is more dominant influence prosocial students' behavior variable (Y). While the value of contribution of independent variables simultaneously (together), namely school culture $\left(\mathrm{X}_{1}\right)$ and scout extracurricular $\left(\mathrm{X}_{2}\right)$ to the behavior of prosocial learners $(\mathrm{Y})$ is $70.4 \%$, while $29.6 \%(100 \%-70,4 \%)$ influenced by other factors or in the other words based on the regression analysis result of two independent variables that is school culture variable $\left(\mathrm{X}_{1}\right)$ and Scout extracurricular variable $\left(\mathrm{X}_{2}\right)$ have significant effect to dependent variable (Y) in elementary school. The results of the data show the value of correlation coefficient of 0.839 and the coefficient of determination 0.704 . This figure implies that school culture $\left(\mathrm{X}_{1}\right)$ and scout extracurricular variable $\left(\mathrm{X}_{2}\right)$ have an influence on prosocial behavior of learners (Y) of $70,4 \%$. While the rest $(100 \%$ $70.4 \%=29.6 \%)$ is influenced by other variables outside this regression model.

\section{CONCLUSION}

\section{A. Conclude}

Based on the results of data analysis of the influence of school culture and Scout extracurricular on the behavior of prosocial learners in elementary school has obtained the result that there is significant influence either partially or simultaneously between the variables studied.

The results obtained as follows. Partially independent variables of school culture $\left(X_{1}\right)$ value is $29.2 \%$ and Scout extracurricular $\left(\mathrm{X}_{2}\right)$ the value is $77.9 \%$. It can be concluded that the independent variable, Scout extracurricular $\left(\mathrm{X}_{2}\right)$, is more dominant in influencing the other variable (Y). While the contribution value of independent variables simultaneously (together) the school culture $\left(\mathrm{X}_{1}\right)$ and Scout extracurricular $\left(\mathrm{X}_{2}\right)$ is $70.4 \%$, while $29.6 \%(100 \%-70.4 \%)$ is influenced by other factors.

This research is important to be carried out in order to be used as a reflection of the state of prosocial behavior of students in school. However, it is also expected that other researchers can conduct similar research that can explore more in the matter of school culture, scout extracurricular and prosocial behavior of students.

\section{B. Advice}

Based on the findings and conclusions of the study, it is expected for elementary school to develop school culture and scout extracurricular by varying further form of rules and activities at school.

\section{REFERENCES}

[1] S. Arikunto, Prosedur Penelitian Suatu Pendekatan Praktik. Jakarta: Rineka Cipta, 2006.

[2] Riduwan. Metode dan Teknik Menyusun Tesis. Bandung: Alfabeta, 2013.

[3] Irianto. Statistik Konsep Dasar dan Aplikasinya. Jakarta: Kencana, 2004.

[4] T. Winarsunu, Statistik dalam Penelitian Psikologi Pendidikan. Malang: UMM Press, 2012. 
[5] S. Raharjo, Cara Uji Normalitas Probability Plot dengan SPP Detail [Online]. Available: https://www.youtube.com/watch?v=txnkclWEuk\&t=575s [Accessed: $22-03-2017$ ]

[6] I, Ghozali, Aplikasi Analisis Multivariate dengan Program SPSS Edisi III. Semarang: Badan Penerbit UNDIP, 2011.

[7] Zamroni. Paradigma Pendidikan Masa Depan. Yogyakarta: Bigraf Publishing, 2011.

[8] Undang-undang RI No. 20 Tahun 2003 Pasal 1 tentang Sistem Pendidikan Nasional.

[9] R. Maslowski, School Culture and School Performance, Disertasi Twente University Press Netherlands, 2001.

[10] R.A. Baron, and D. Byrne, Psikologi Sosial Edisi 10. Jakarta: Erlangga, 2007.

[11] H. Gunawan, Pendidikan Karakter Konsep dan Implementasi. Bandung: Alfabeta, 2012.

[12] D. Rahmatika, Buku Pintar Pramuka Edisi Pelajar. Jakarta: Bee Media Pustaka, 2015. 